\title{
Population Development in Finland in the 1980s
}

\section{MARKETTA RITAMIES}

\author{
Research Associate \\ The Population Research Institute
}

Population questions, especially low fertility, were subjects of much discussion in Finland in the 1980s. No great changes occurred in population development during the past decade, however. On the contrary, the $1980 \mathrm{~s}$ can be considered a period of stabilization, a period when the developmental trends observed in the previous decades slowed down and became stable. Finland was approaching zero growth, fertility and mortality remained at a low level and migration stabilized. However, more long-term changes in population development were clearly manifested during this decade, for example, in the small size of the young age groups in the populations's age structure and the increase in old age groups. These changes were the focus of much attention, especially for reasons of labor policy.

\section{Nuptiality and fertility}

During the $1980 \mathrm{~s}$, year by year, fewer and fewer marriages were contracted. At the end of the decade, about 15 percent fewer marriages were contracted than in the beginning (Table 1). At the same time, the age at first marriage continued its rise from the previous decade. It climbed up about 1.3 years during the 1980 s or from 23.7 to 25.0 for women and from 25.6 to 26.8 years for men (Table 1).

The main reason for the growing age at first marriage is most likely increasing cohabitation without marriage. The number of consensual unions rose during the decade by about 40 percent (Table 1). Even if there are no data on the growth of consensual unions during the previous decade, it is obvious that the increase in relative terms was greater than in the 1980s. In absolute figures, however, there were rather few consensual unions. They now form about 15 percent of all unions, i.e. marriages and consensual unions. Still, most or three-fourths of the consensual unions are childless. This means that a great part of the consensual unions are between young people who do not yet have children.

At the end of the decade two-thirds of all consensual unions were established by partners aged 15-24, while the corresponding proportion in the beginning of the period was only 44 percent. A growing number of conjugal unions start with cohabitation without marriage. However, many, and probably most, consensual unions end in marriage. It is rather common to marry when a child is on the way. Nevertheless, the number of consensual unions with children is growing and, now, roughly onethird of all consensual unions have children under 18 years of age.

An up-and-down movement typical of low fertility societies put its imprint on the fertility trends in Finland during the 1980s. However, the changes have not been very significant and, on the whole, the impression is that fertility in the 1980 s has remained more or less unchanged throughout the entire decade. Compared with the Nordic and Western European countries, except for Sweden, fertility in Finland has been high. 
Table 1. Marriages contracted, median age at first marriage, consensual unions and their proportion of all unions.

\begin{tabular}{|c|c|c|c|c|c|}
\hline & \multirow[t]{2}{*}{$\begin{array}{l}\text { Marriages } \\
\text { contracted }\end{array}$} & \multicolumn{2}{|c|}{$\begin{array}{c}\text { Median age } \\
\text { at first marriage }\end{array}$} & \multicolumn{2}{|c|}{$\begin{array}{l}\text { Consensual unions } \\
\text { Number } \quad \%\end{array}$} \\
\hline & & $\mathrm{M}$ & $\mathrm{F}$ & & \\
\hline 1980 & 29388 & 25.6 & 23.7 & 200000 & \\
\hline 1981 & 30100 & 25.8 & 23.8 & 214000 & 10.3 \\
\hline 1982 & 30459 & 26.0 & 24.0 & 227000 & 10.9 \\
\hline 1983 & 29474 & 26.1 & 24.1 & 235000 & 11.2 \\
\hline 1984 & 28550 & 26.4 & 24.4 & 263000 & 12.2 \\
\hline 1985 & 25751 & 26.6 & 24.5 & 283000 & 12.8 \\
\hline 1986 & 25820 & 26.8 & 24.9 & 304000 & 14.0 \\
\hline 1987 & 26376 & 26.8 & 25.0 & 324000 & 14.8 \\
\hline $1988^{*}$ & 26453 & & & & \\
\hline $1989 *$ & 25043 & & & & \\
\hline
\end{tabular}

* Preliminary data

Source: CSO Population 1980 - 1987, 1982 - 1990; Families 1980-1987, 1982-1989; unpublished data from the Central Statistical Office.

Table 2. Live births, crude birth rate and total fertility rate.

$\begin{array}{lccc} & \text { Live births } & \begin{array}{c}\text { Crude } \\ \text { birth rate }\end{array} & \begin{array}{c}\text { Total } \\ \text { fertility rate }\end{array} \\ 1980 & 63064 & 13.2 & 1.64 \\ 1981 & 63469 & 13.2 & 1.65 \\ 1982 & 66106 & 13.7 & 1.72 \\ 1983 & 66892 & 13.8 & 1.74 \\ 1984 & 65076 & 13.3 & 1.70 \\ 1985 & 62796 & 12.8 & 1.64 \\ 1986 & 60632 & 12.3 & 1.60 \\ 1987 & 59827 & 12.1 & 1.59 \\ 1988^{*} & 63313 & 12.8 & 1.70 \\ 1989^{*} & 63388 & 12.8 & \end{array}$

* Preliminary data

Source: CSO Population 1980 - 1987, 1982 - 1990; Preliminary unpublished data from the Central Statistical Office.

The total number of children born has varied between 60,000 and 67,000 , with the lowest crude birthrate at 12.1 and the highest at 13.8 (Table 2). In the beginning of the decade, a fertility increase was noted which culminated in 1983. After that a decline followed which reached its low point in 1987. Towards the end of the decade fertility again increased. In 1990, apparently the same rates will be reached as in the beginning of the decade.

The increase in fertility in the beginning of the 1980 s was the topic of a lively discussion in the press. Later a more thorough analysis of the increase was made. It appeared that it was a more or less general phenomenon with growing rates in all age groups. Proportionally, the augmentation was most pronounced in the mature age groups, those aged 40-45. However, their share of all babies born is rather small and the rise must consequently be credited to the younger, more fertile groups. It also appeared that the increase was most prominent in the uppermost income group. The reasons why the climate for a baby boom originated are still more or less unknown. 
The age-specific fertility rates showed a declining tendency in almost all age groups in the beginning of the decade (Figure 1). The increase was clearly seen in the age groups $25-29$ and $30-34$. Around the middle of the decade a small downward trend appeared which towards the end of the period again went up. It is interesting to note that the age group $40-44$ has shown a continuous rise throughout the decade. The completed fertility rate, which is based on yearly age-specific fertility rates and reflects development rather well, shows rather small variations, ranging from 1.60 to 1.74 (Table 2).

The rise of the age of the mother at first child, already typical of the preceding decade, continued and rose from 25.2 to 26.1 years. The rise of the age at first child contributes to smaller families and childlessness. Distribution of birth according to birth order shows that the proportion of births by first order has decreased and the births by third and subsequent order have increased during the $1980 \mathrm{~s}$. The number of women aged $20-34$ has diminished by only about six percent, those aged $20-24$ less and those aged 30-34 years somewhat more. Consequently, the changes in birth order proportion seem to point to a tendency toward less family formation, to postponement of having children (Table 3 ).

The postponed children were presumably born, partly at least, at the end of the decade and in 1990. At the same time as fewer children of first parity were born, an increase of the third and higher parity was noted. In reality, the higher proportion of third and higher birth order tells us only that the frequency of giving birth to children of these birth orders has remained more or less unchanged during the decade.

The increase of children born out of wedlock also reflects the trend towards more consensual unions. Proportionally, the growth has been significant even if smaller than during the preceding decade, or from 13.1 percent of all live births in 1980 to 19.0 in 1987 . In absolute terms, it means a growth of only some 3,000 children, which, of course, is only a small fraction of the increase of the number of consensual unions during the decade (Table 4).

Figure 1. Age-specific fertility rates $1980-1988$.

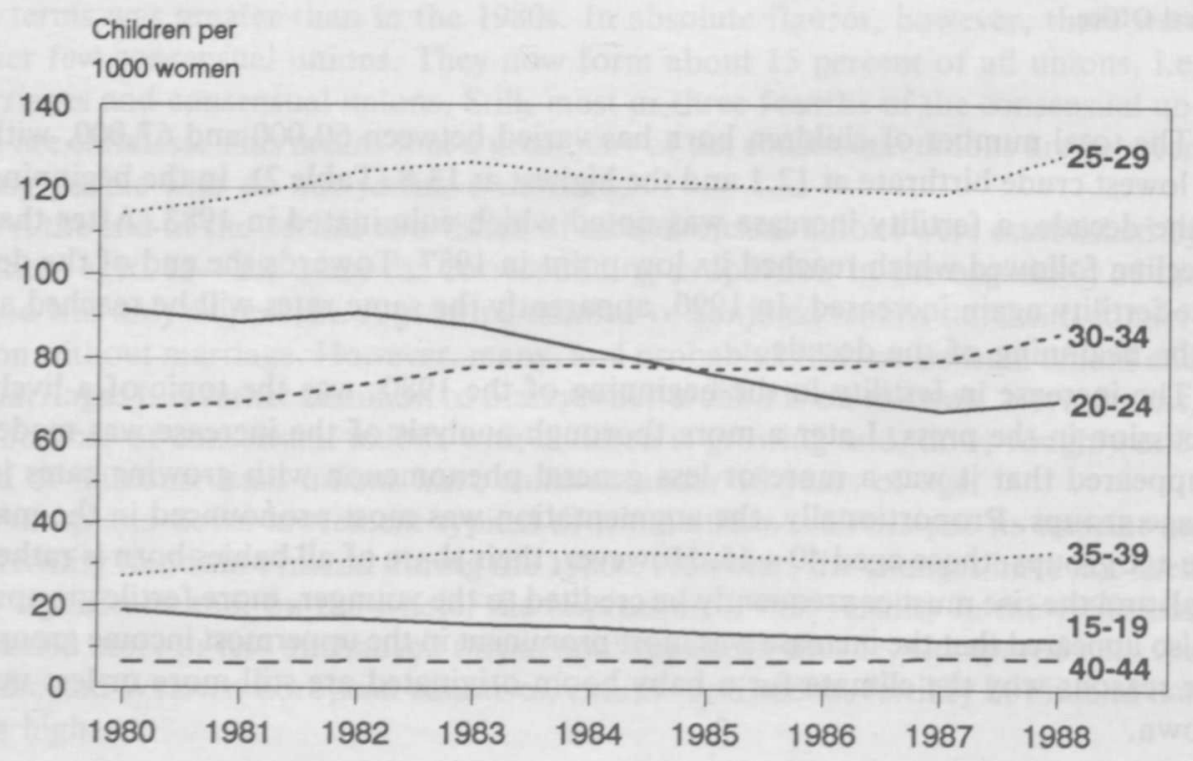


Table 3. Births by birth order as a percentage of all births, 1980-1988.

$\begin{array}{ccccc} & \text { I } & \text { II } & \text { III- } & \text { Live births } \\ 1980 & 46.9 & 35.5 & 17.6 & 63,064 \\ 1981 & 46.5 & 35.1 & 18.4 & 63,469 \\ 1982 & 40.9 & 36.7 & 22.4 & 66,106 \\ 1983 & 39.6 & 36.7 & 23.7 & 66,892 \\ 1984 & 39.1 & 36.1 & 24.8 & 65,076 \\ 1985 & 39.3 & 35.7 & 25.0 & 62,796 \\ 1986 & 39.0 & 36.1 & 24.9 & 60,632 \\ 1987 & 39.6 & 35.6 & 24.7 & 59,827 \\ 1988 & & & & 63,313\end{array}$

Source: CSO Population 1980-1987, 1982-1990.

Table 4. Children born out of wedlock, 1980-1989.

$\begin{array}{ccc}\text { Number } & \begin{array}{c}\text { Percent of all } \\ \text { live births }\end{array} \\ 1980 & 8,247 & 13.1 \\ 1981 & 8,431 & 13.3 \\ 1982 & 9,007 & 13.6 \\ 1983 & 9,386 & 14.0 \\ 1984 & 9,825 & 15.1 \\ 1985 & 10,292 & 16.4 \\ 1986 & 10,931 & 18.0 \\ 1987 & 11,467 & 19.0\end{array}$

Source: CSO Population 1980-1987, 1982-1990.

The regional differences in fertility narrowed down in the $1980 \mathrm{~s}$. The difference in total fertility figures between the province of Oulu, which had the highest fertility at the beginning of the decade, and the province of Uusimaa, which had the lowest, was 48 percent. In 1987 the corresponding difference in fertility between the lowest and the highest was 34 percent, but instead of in the province of Uusimaa total fertility was then lowest in the province of Kymi. A general trend in the 1980s was a decline in fertility in almost all parts of the country. Total fertility rose slightly from 1980 to 1987 only in the provinces of Uusimaa and Häme, which was apparently related to the favorable development of migration in these provinces.

Abortion figures developed favorably in the 1980s. Already during the previous decade, starting in 1973, the number of abortions had begun to decline, and the same trend was maintained throughout the 1980s. The free abortion law of 1970 thus did not lead to an increase in abortions, except for a few years after the law was enacted. Abortions have not become a means of contraception in Finland. While the number of abortions performed in the 1970 s totaled 196,000 , the corresponding figure for the 1980 s was 135,000 . As the 1980 s came to an end, the annual number of abortions was less than 20 percent of live births, that is, a good 12,000 .

The Finnish abortion situation is good compared to that in most European countries. Family planning has generally been adopted and undesired pregnancies can mostly be prevented. Abortions have diminished in all age groups and in all parts of the country. Nevertheless, the abortion figures for young people have gone down less than in the other age groups. 


\section{Mortality}

No significant changes in mortality occurred in the 1980s. The low mortality level already reached in the 1960 s remained at more or less the same level. The general mortality rate stayed under 10 per thousand. Infant mortality dropped and the mean expectation of life rose, although both more slowly than in the previous decade.

The number of deaths varied in the 1980 s between 44,000 and 49,000 . The clearest annual mortality difference arose in the middle of the decade, when the general mortality rate increased from 9.2 persons per 1,000 inhabitants in 1984 to 9.8 in 1985 . After the mid-1980s mortality declined somewhat, but at the end of the decade 9.9 persons per 1,000 inhabitants died. The rise in the mortality rate at the end of the decade is most likely connected with the aging of the population. In the 1980 s the proportion of the population having reached 65 years of age grew from 12.0 percent to 13.3 percent.

An examination of age-specific mortality figures revealed that the definite increase, noted above, in the general mortality rate in 1985 was caused, above all, by an increase in mortality in the old age groups. This, again, may have been related to an unusually cold winter, whose impact was most readily felt in the health of the elderly.

The favorable development in mortality, reflected in the lengthening of the mean expectation of life, continued in the 1980 s, but more slowly than during the preceding decade. Especially at the end of the decade, in 1986-88, this growth ceased. While the life expectancy of both men and women increased by more than three years in the 1970 s, in the 1980 s, by 1988 , the life expectancy of women increased by only 1.1 year and that of men by 1.5 . In 1988 women lived, on the average, to the age of 78.7 and men to the age of 70.7 (Table 5).

The more rapid increase in life expectancy occurring in the 1970 s was a result of the decrease of mortality in all age groups. On the other hand, in the 1980s, the decrease in mortality among 15-49-year-olds was slow, because female mortality remained about the same and that of men decreased more slowly than in the older age groups. The decline in the mortality of young children was more marked than in the other age groups (Koskinen 1989, 3).

Table 5. Crude death rate, infant mortality rate and mean expectation of life at birth in the 1980s.

\begin{tabular}{ccccc}
$\begin{array}{c}\text { Deaths per } \\
1,000 \text { of mean } \\
\text { population }\end{array}$ & $\begin{array}{c}\text { Infant mortality } \\
\text { per } 1,000 \text { live } \\
\text { births }\end{array}$ & \multicolumn{2}{c}{$\begin{array}{c}\text { Mean expectation } \\
\text { of life at birth } \\
\text { Men }\end{array}$} \\
1980 & 9.2 & 7.6 & 69.2 & Women \\
1981 & 9.3 & 6.5 & 69.5 & 77.6 \\
1982 & 9.0 & 6.0 & 70.1 & 78.8 \\
1983 & 9.3 & 6.2 & 70.2 & 78.0 \\
1984 & 9.2 & 6.5 & 70.4 & 78.7 \\
1985 & 9.8 & 6.3 & 70.1 & 78.5 \\
1986 & 9.6 & 5.8 & 70.5 & 78.7 \\
1987 & 9.7 & 6.2 & 70.7 & 78.7 \\
1988 & 9.9 & 6.1 & 70.7 & 78.7 \\
1989 & 9.9 &.. &.. &..
\end{tabular}

Source: CSO Population 1980-1987, 1982-1990. 
In examining the development of mortality in the $1980 \mathrm{~s}$, on the basis of probability of death, there were signs of a phenomenon which is probably related to the slowing down of the decrease in mortality among the 15-49-year age group. From the beginning of the decade up to 1988 the probability of death declined in all age groups over 55 and in most groups under the age of 30 . On the other hand, the death probability increased for the 30-49-year-olds. The probability of death grew, above all, among the large age groups, meaning those born during the latter part of the 1940s. The probability of death increased for men in all birth cohorts of the 35-44-year age group, but for women in only a few. We are not really aware of the reasons for this phenomenon, because it was not until very recently that the increased probability of death of the large age groups have been observed. One reason thought to be a likely cause is the stress inherent in the lifestyle people lead.

The mortality of children under one year of age was already so low at the end of the 1970s that infant mortality could no longer decrease in the 1980 s at the same rate as in previous decades. The annual fluctuations visible in the mortality figures for the under-one-year-olds may be caused by very small changes in the number of deaths. In 1986 infant mortality was 5.8 per thousand, less than ever before. In 1988 6.1 children died per 1,000 live births (Table 5). Infant mortality in the Nordic countries at the end of the 1980s was the lowest in the world, with it even slightly lower in Iceland than in Sweden and in Finland.

The excess mortality of men has been a feature typical of Finnish mortality for a long time, a feature which is not as readily apparent in other developed countries. The excess mortality of men, which was accentuated in the older age groups at the end of the 1930 s and the early 1940 s, has gradually changed so that it encompasses all adult age groups. The greater mortality of men compared to women shows up in the differences between the sexes in the mean expectation of life. In 1988 women lived eight years longer than men. Nevertheless, the differences had decreased slightly compared to the previous decade. In 1977, when the differences in the mean expectation of life of men and women was at its greatest, it was 8.8 years.

The excess mortality of Finnish males continues to be one of the highest in the world. In childhood the excess mortality of men in the 1980 s was about 1.5 times that of women, but in the working-age age group it was three times that of women. Among the elderly the relative difference decreases with age (Koskinen 1989, 6).

There have also been notable regional differences in Finnish mortality for a long time already. In the 1980 s mortality increased, as in previous decades, when going from the country's western regions to the eastern and northern ones. The mortality of middle-aged men, especially, was markedly high in these parts of the country. This phenomenon has long been found to be related to, for one, the incidence of vascular diseases in Eastern and Northern Finland (Koskinen 1989, 7-8).

\section{Migration}

In the 1960 s and the 1970 s Finland experienced one of the most rapid internal migration movements of the western world. The population migrated from agriculture and the rural areas to industry and the urban areas. The structural transition also included intense migration to Sweden. In the 1980s, however, the situation began to stabilize. Internal migration was relatively steady and emigration turned into immigration.

In Finland the annual number of internal migrants remained at somewhat less than 200,000 persons through the 1980 s, until 1987 . After this the number of migrants 
exceeded the 200,000 mark and in 1989 about 217,00 persons changed their municipality of residence.

Internal migration had earlier been directed primarily to the large urban centers and especially to the Helsinki metropolitan area. In the 1980s the growth of the large cities slowed down, and even ceased entirely. The difficult housing situation in the cities was the major reason for the retardation in migration. In the metropolitan area the price of housing was an average of 50 percent higher than elsewhere in the country, which is why people wanted to leave and move to a more pleasant living environment (Koivukangas 1990).

Migration between urban areas in the 1980 s remained rather active and rural-tourban migration was relatively stable. From 1987 on, migration from urban areas to rural areas increased, with migration between rural municipalities decreasing slightly (Table 6). Migration within municipalities was especially intense in the 1980 s because housing changed hands frequently during the prevailing financial boom period.

As a result of migration, Finland's population has flowed south. Jobs are situated in Uusimaa and in the provincial urban centers. Uusimaa experienced a continuous migration gain up to 1987 , but in the last two years of the decade net migration decreased strongly. In the province of Häme migration was on the rise. Keski-Suomi also had a favorable developmental trend. In the province of Kymi, however, migration losses have increased. At the end of the decade, in particular, migration loss figures had taken a turn for the better in Eastern Finland. In the 1980s migration loss was highest in Northern Finland and in the province of Vaasa. The situation was poor especially in the province of Lappi (Korkiasaari 1990, 2-3).

Internal migration in the 1980 s was almost as common among men as among women. The tendency to migrate increased slightly among the unmarried and decreased among the others. Those most inclined to migrate were people with an upper second-level education. On the other hand, the willingness of the highly trained to migrate decreased most markedly. Nevertheless, at the very end of the decade, the increase in internal migration has raised the propensity to migrate in all education groups. Only among groups with a basic-level education did the tendency to migrate remain about the same throughout the entire decade (Korkiasaari 1990, 4-5).

The slowing down of internal migration in the 1980s was not typical only of Finland, however, instead a similar phenomenon has been observed in most OECD countries. It has also been noted that, in the Western countries, both unemployed workers and vacant jobs have been found on the labor market at the same time. One ex-

Table 6. The direction of internal migration flow and net migration in the 1980 s.

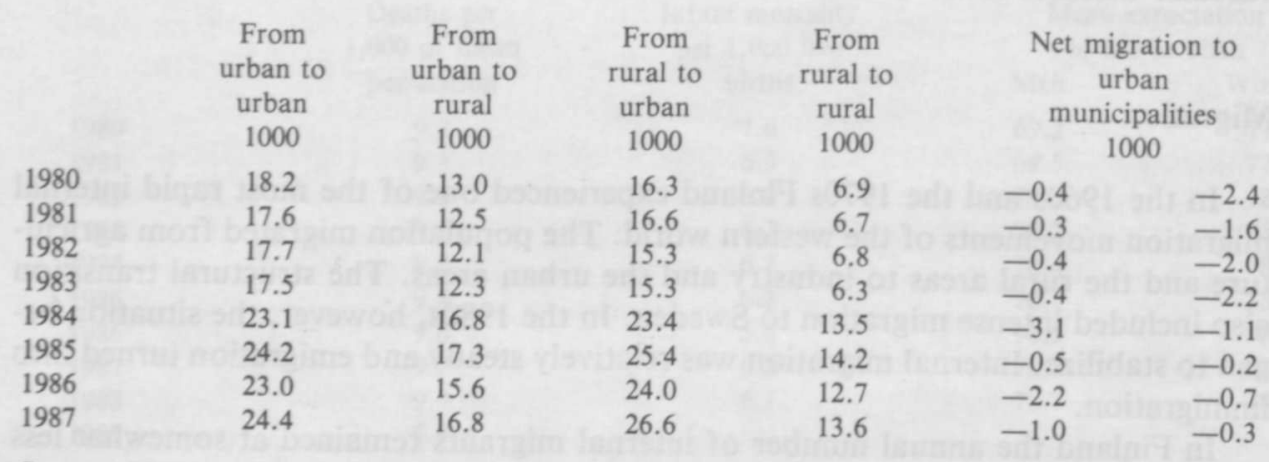

Source: CSO Population 1980-1987, 1982-1990. 
Figure 2. Immigration and emigration in 1980-89.

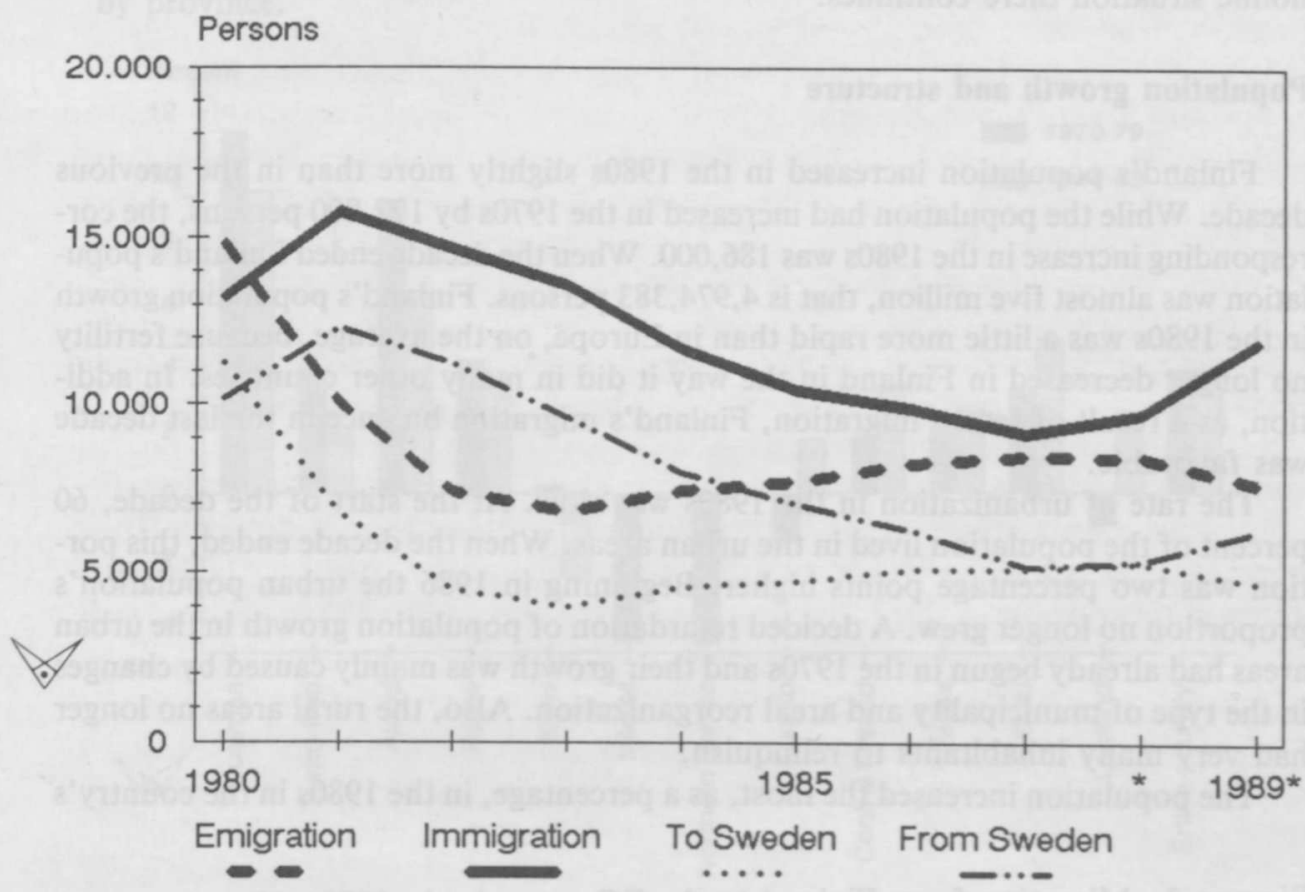

Source: CSO Population 1980-1988, 1982-1991

planation given for this imbalance in the labor market has been the decrease in the mobility of labor (Korkiasaari 1990, 2).

Emigration, which in the 1960s and 1970s followed Sweden's economic development and was the inverse of Finland's economic development, was no longer significant as an escape valve in the 1980s. Finland's economic situation was good. Unemployment decreased and the gross domestic product grew rapidly. At the end of the decade Finland's gross domestic product per capita reached the level in Sweden. This favorable development could be seen also in the transformation of the migration balance into a positive one. While Finland had lost 63,000 inhabitants as emigrants in the 1970 s, mainly to Sweden, in the 1980 s the number of return migrants was already about 27,000 greater than the number of emigrants (Figure 2).

Emigration in the 1980 s was directed mainly to Sweden, as in the previous decade, but in the latter half of the decade, the relative proportion of emigrants absorbed by the Nordic countries decreased. Correspondingly, more Finns moved to other countries in Europe, mostly to the Federal Republic of Germany and to Great Britain and pensioners to Spain. There were also more return migrants from these countries (Figure 3).

In the 1980 s, especially toward the end of the decade, migration was characterized by the strengthening of immigration to Finland from the East European countries, especially from the Soviet Union. In 1980 - 87 over 3,000 persons migrated from the Soviet Union to Finland. Over one-half of these people were Ingrian Finns. The return migrant status they had attained was one reason for the growth in the migration. There are about 100,000 people of Finnish origin in the Soviet Union, whose 
willingness to move to Finland will apparently increase, if the current difficult economic situation there continues.

\section{Population growth and structure}

Finland's population increased in the 1980s slightly more than in the previous decade. While the population had increased in the 1970 s by 172,800 persons, the corresponding increase in the 1980 s was 186,000 . When the decade ended Finland's population was almost five million, that is $4,974,383$ persons. Finland's population growth in the 1980s was a little more rapid than in Europe, on the average, because fertility no longer decreased in Finland in the way it did in many other countries. In addition, as a result of return migration, Finland's migration balance in the last decade was favorable.

The rate of urbanization in the $1980 \mathrm{~s}$ was slow. At the start of the decade, 60 percent of the population lived in the urban areas. When the decade ended, this portion was two percentage points higher. Beginning in 1986 the urban population's proportion no longer grew. A decided retardation of population growth in the urban areas had already begun in the 1970 s and their growth was mainly caused by changes in the type of municipality and areal reorganization. Also, the rural areas no longer had very many inhabitants to relinquish.

The population increased the most, as a percentage, in the 1980s in the country's

Figure 3. Migration from Finland to the EC-countries in 1980-88.

Countries

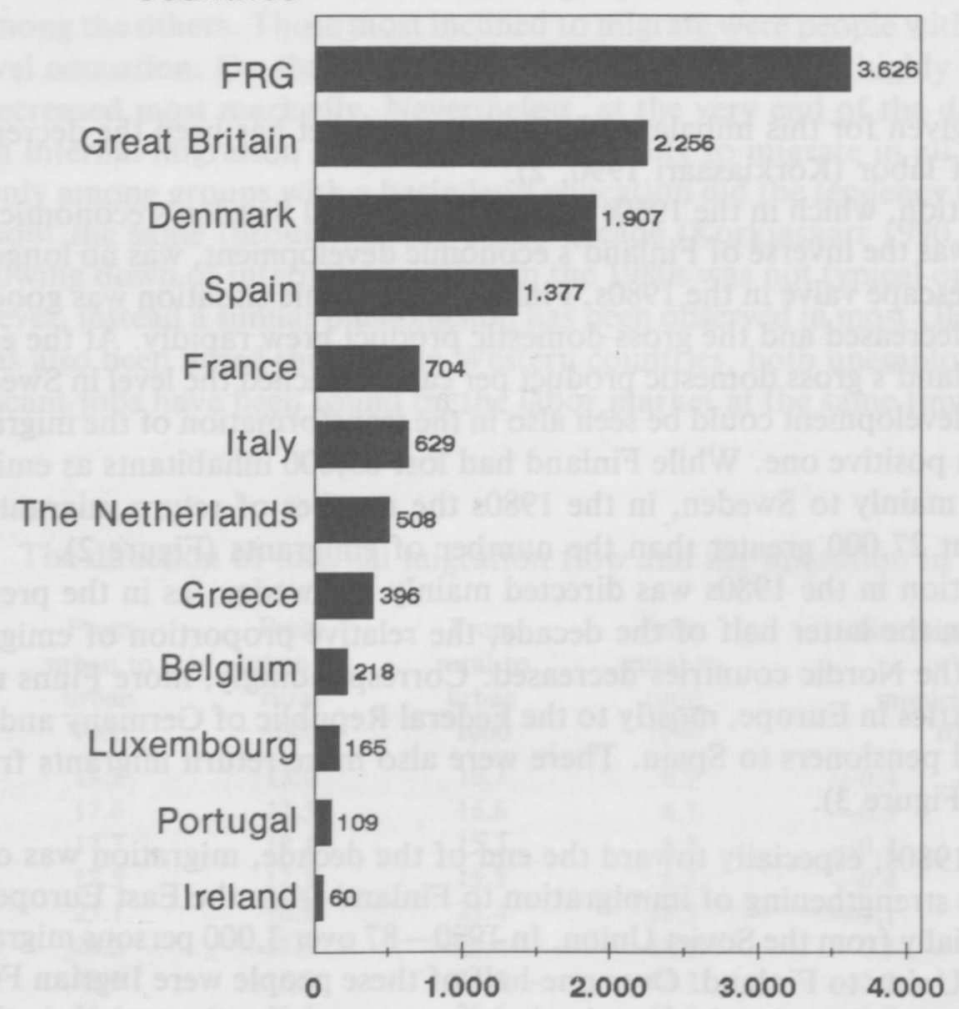


Figure 4. The percentage of change in the population in $1970-79$ and $1980-89$, by province.

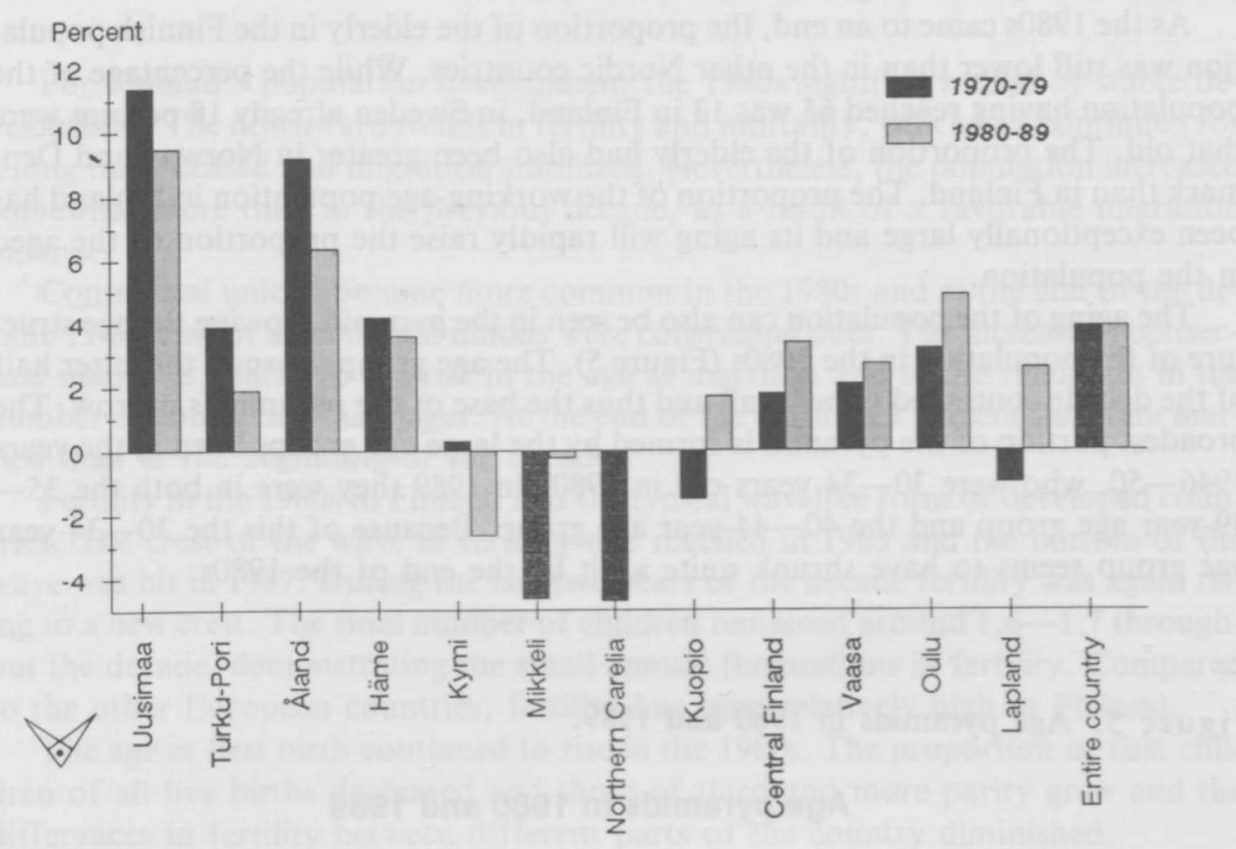

southern and southwestern regions, although, compared to the previous decade, growth had slowed down somewhat. Uusimaa and especially the Helsinki metropolitan area continued to attract their share of inhabitants. The population also increased quite strongly in the provinces of Oulu and Keski-Suomi, even more than in the 1970s. While in the previous decade Eastern Finland, meaning the provinces of Mikkeli, Pohjois-Karjala and Kuopio, were regions of population loss, in the 1980s only the province of Mikkeli had a slightly negative migration balance. While in the 1970s migration loss was greatest in the province of Mikkeli, in the 1980s population development was the most negative in the province of Kymi (Figure 4).

The special features of Finland's population development, the decrease in fertility beginning later than in the other European countries as well as the later onset but stronger decline of mortality and the birth of the large age groups in the latter half of the 1940s, show up in the development of Finland's population structure, which deviates somewhat from that of other West European countries. The last large age groups from around the 1910s reached retirement age in the 1970s and the proportion of the population made up by the elderly grew quickly. The strong decrease in mortality also increased the size of the age groups reaching pensionable age. Because of the large age groups the proportion of children in Finland in the 1950s was great and that of the working-age population small. Coming into the 1970 s the proportion of children declined and that of the working-age population grew (Valkonen 1990, $231-32$ ).

The aging of the population's age structure continued in the 1980 s, but more slowly than in the previous decade. The proportion of the elderly, those having reached 65 years of age, increased by 11 percent in the 1980 s, in the previous decade the corresponding growth was 28 percent. Respectively, the proportion of the population under 15 years of age decreased by only four percent, but the corresponding decline 
in the 1970 s had been 17 percent. The share of the working-age population no longer grew as it had in the preceding decade, instead it declined slightly. In 1989 the proportion of the population aged $15-64$ was 67 percent.

As the 1980s came to an end, the proportion of the elderly in the Finnish population was still lower than in the other Nordic countries. While the percentage of the population having reached 65 was 13 in Finland, in Sweden already 18 percent were that old. The proportion of the elderly had also been greater in Norway and Denmark than in Finland. The proportion of the working-age population in Finland has been exceptionally large and its aging will rapidly raise the proportion of the aged in the population.

The aging of the population can also be seen in the pyramid showing the age structure of the population in the 1980s (Figure 5). The age groups born in the latter half of the decade continued to be small and thus the base of the pyramid is narrow. The broadest portion of the pyramid is formed by the large age groups born in the years 1946-50, who were 30-34 years old in 1980. In 1989 they were in both the 3539 -year age group and the 40-44-year age group. Because of this the 30-34-year age group seems to have shrunk quite a bit by the end of the 1980 s.

Figure 5. Age pyramids in 1980 and 1989.

\section{Age pyramids in 1980 and 1989}
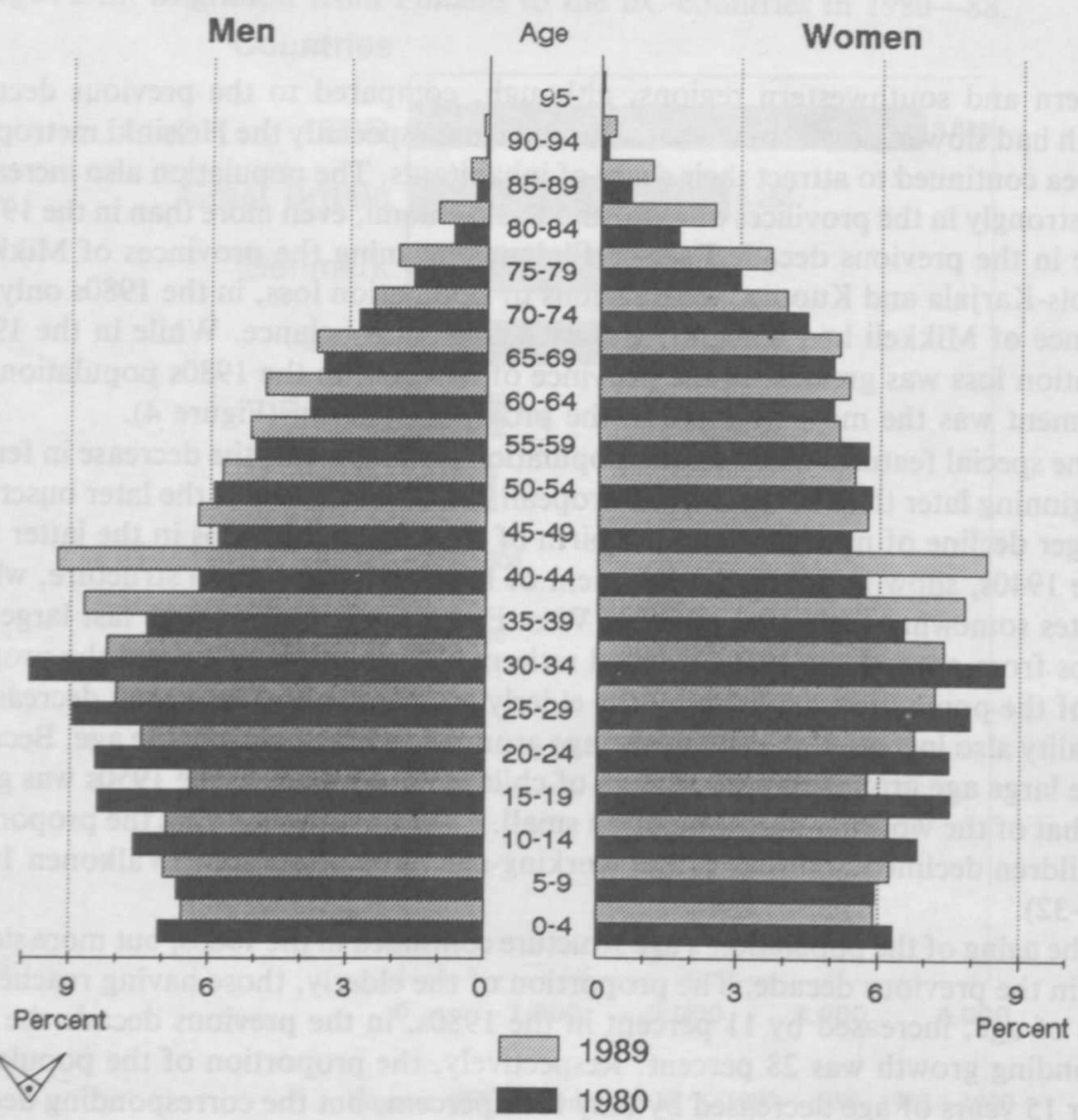
For Finland's population development the 1980s signified a time of stable development. The downward trends in fertility and mortality, which had continued for a long time, ceased and migration stabilized. Nevertheless, the population increased somewhat more than in the previous decade, as a result of a favorable migration balance.

Consensual unions became more common in the 1980 s and at the end of the decade 15 percent of all conjugal unions were consensual ones. The increase in consensual unions is related to the rise in the age at marriage and to the reduction in the number of contracted marriages. At the end of the decade 15 percent less were married than at the beginning of the decade.

Fertility in the 1980s in Finland had the typical wavelike form of developed countries. The crest of the wave in fertility was reached in 1983 and the bottom of the wave was hit in 1987 . During the last two years of the decade fertility was again rising to a new crest. The final number of children remained around $1.6-1.7$ throughout the decade, demonstrating the small annual fluctuations in fertility. Compared to the other European countries, fertility has been relatively high in Finland.

The age at first birth continued to rise in the 1980s. The proportion of first children of all live births decreased and those of third and more parity grew and the differences in fertility between different parts of the country diminished.

There were both positive and negative features in the development of mortality in the $1980 \mathrm{~s}$. The general mortality rate remained quite stable, rising slightly as the age structure of the population aged at the end of the decade. Infant mortality continued to decline and at the end of the decade it was almost the lowest in the world. On the other hand, the decline in the mortality of the working-age population in their prime, those under 50 years of age, came to a stop. The mean expectation of life increased, but more slowly than in the previous decades. Men continued to die at a clearly younger age than women, but compared to the 1970 s the difference between the sexes diminished slightly.

The stabilization of migration became apparent, first of all, in the annual numbers of internal migrants remaining at about the same level up to the end of the decade. Migration directed toward urban areas and the southern parts of the country slowed down. Similarly, inter-urban migration and migration to rural areas increased. The largest migration loss regions of the previous decades, Eastern and Northern Finland, improved their standing, while the province of Kymi suffered a migration loss.

The decrease in internal migration was also a sign of stabilization in migration in the 1980s. The improvement of Finland's economic situation strengthened return migration and made the migration balance positive. Migration continued to be strongest between the Nordic countries, but Finns also began to discover the rest of Europe. Finland, again, became increasingly the goal to migration for a growing number of East Europeans, especially toward the end of the decade.

The continuing of the low level of fertility and mortality was reflected in the aging of the population's age structure. Although the proportion of those having reached the age of 65 at the end of the 1980s was even lower in Finland than in the other Nordic countries, her population is nevertheless aging rapidly. With the aging of a markedly large working-age population, the proportion of the elderly will increase strongly. 


\section{References}

CSO (1982 - 1989). Families 1980-1987. Helsinki: Central Statistical Office of Finland.

CSO (1982-1988). VI A: 145-153. Population 1980-1986. Volume I. Helsinki.

CSO Population 1989: 1. Avoliitossa elävät (Consensual unions). Helsinki.

CSO Population 1989: 10. Vital Statistics by Municipality 1987. Helsinki.

CSO Population 1990: 12. Structure of Population 1989. Helsinki.

CSO Statistical Yearbook of Finland 1981, 1984, 1990 (1982, 1985, 1990). Helsinki.

Koivukangas, Olavi (1990). Suomessa vuosina 1970-1990 tapahtuneet muuttoliikeilmiöt ja tutkimustilanne (Internal migration in Finland 1970-1990 and the state of research). Paper presented at Muuttoliikesymposium 19.-21. 11. 1990, Turku. Turku: Institute of Migration. Unpublished

Korkiasaari, Jouni (1990). Maassamuutto ja rakennemuutos - Suomi ja muu Pohjola (Internal migration and the structural change - Finland and the other Nordic countries). Paper presented in Muuttoliikesymposium 19.-21. 11. 1990, Turku. Turku: Institute of Migration. Unpublished

Koskinen, Seppo (1989). Kuolleisuuden pieneneminen hidastunut 1980-luvulla (The decrease in mortality has slowed down in the 1980s). Sosiaalinen aikakauskirja 83 (2): 3-9.

Valkonen, Tapani (1990). Väestönkehitys (Population development). In: Suomi 2017, edited by Olavi Riihinen, pp. 227-245. Jyväskylä: Gummerus.

Yearbook of Population Research in Finland (1981). Vol. 19. Helsinki. 